\title{
Perivascular Adipose Tissue and Cardiometabolic Disease
}

\author{
Anna Meiliana ${ }^{1,2, *}$, Andi Wijaya ${ }^{1,2}$ \\ ${ }^{1}$ Postgraduate Program in Clinical Biochemistry, Hasanuddin University, Jl. Perintis Kemerdekaan Km.10, Makassar, Indonesia \\ ${ }^{2}$ Prodia Clinical Laboratory, Jl. Cisangkuy No.2, Bandung, Indonesia \\ *Corresponding author. E-mail: anna.meiliana@prodia.co.id
}

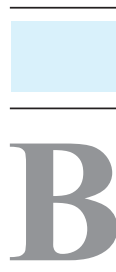

\section{Abstract}

ACKGROUND: Obesity is associated with insulin resistance, hypertension, and cardiovascular disease, but the mechanisms underlying these associations are incompletely understood. Microvascular dysfunction may play an important role in the pathogenesis of both insulin resistance and hypertension in obesity.

CONTENT: Perivascular adipose tissue (PVAT) is a local deposit of adipose tissue surrounding the vasculature. PVAT is present throughout the body and has been shown to have a local effect on blood vessels. The influence of PVAT on the vasculature changes with increasing adiposity. PVAT similarly to other fat depots, is metabolically active, secreting a wide array of bioactive substances, termed 'adipokines'. Adipokines include cytokines, chemokines and hormones that can act in a paracrine, autocrine or endocrine fashion. Many of the proinflammatory adipokines upregulated in obesity are known to influence vascular function, including endothelial function, oxidative stress, vascular stiffness and smooth muscle migration. Adipokines also stimulate immune cell migration into the vascular wall, potentially contributing to the inflammation found in atherosclerosis. Finally, adipokines modulate the effect of insulin on the vasculature, thereby decreasing insulin-mediated muscle glucose uptake. This leads to alterations in nitric oxide signaling, insulin resistance and potentially atherogenesis.

SUMMARY: PVAT surrounds blood vessels. PVAT and the adventitial layer of blood vessels are in direct contact with each other. Healthy PVAT secretes adipokines and regulates vascular function. Obesity is associated with changes in adipokine secretion and the resultant inflammation of PVAT. The dysregulation of adipokines changes the effect of PVAT on the vasculature. Changes in perivascular adipokines secretion in obesity appear to contribute to the development of obesity-mediated vascular disease.

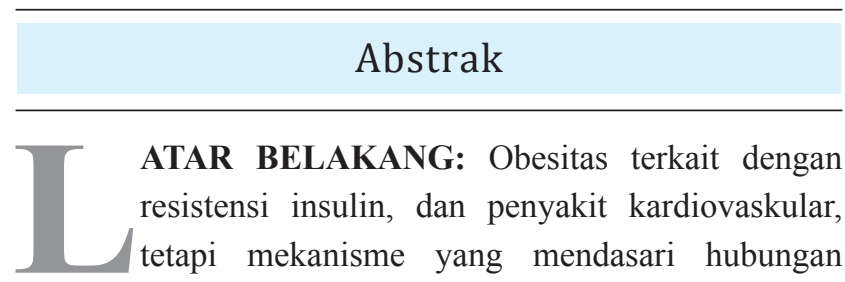

tersebut belum sepenuhnya dipahami. Disfungsi mikrovaskular memiliki peran penting pada patogenesis baik resistensi insulin maupun hipertensi pada obesitas.

ISI: Jaringan lemak perivaskular merupakan jaringan adiposa lokal yang terkumpul di sekeliling pembuluh darah. Jaringan lemak perivaskular ditemukan di seluruh tubuh dan terbukti memiliki pengaruh pada pembuluh darah. Pengaruh ini berubah sesuai dengan peningkatan adipositas. Sama seperti penyimpanan lemak yang lain, jaringan lemak perivaskular aktif secara metabolik, mensekresikan berbagai macam zat bioaktif yang disebut "adipokin". Adipokin terdiri dari sitokin, kemokin, dan hormon yang bekerja secara parakrin, otokrin atau endokrin. Beberapa adipokin yang meningkat pada obesitas dapat mempengaruhi fungsi vaskular, termasuk fungsi endotel, stres oksidatif, kekakuan vaskular dan migrasi sel otot polos. Adipokin menstimulasi migrasi sel imun menuju ke dinding vaskular, yang berperan terhadap inflamasi pada aterosklerosis. Akhirnya, adipokin memodulasi kerja insulin pada pembuluh darah, yaitu menurunkan uptake glukosa otot yang dimediasi oleh insulin. Hal ini memicu perubahan signaling nitrit oksida, resistensi insulin, dan berpotensi memicu terjadinya aterosklerosis.

RINGKASAN: Jaringan lemak perivaskular mengelilingi pembuluh darah. Jaringan lemak perivaskular dan lapisan adventitial pada pembuluh darah berkomunikasi secara langsung satu sama lain. Jaringan lemak perivaskular yang sehat mensekresikan adipokin dan mengatur fungsi vaskular. Obesitas terkait dengan perubahan sekresi adipokin jaringan lemak perivaskular dan menyebabkan inflamasi. Disregulasi 
KEYWORDS: obesity, perivascular adipose tissue, PVAT, cardiometabolic disease, adipokine

Indones Biomed J. 2013; 5(1): 13-24 adipokin merubah pengaruh jaringan lemak perivaskular terhadap pembuluh darah. Perubahan sekresi adipokin perivaskular pada obesitas berperan terhadap perkembangan obesitas menjadi penyakit vaskular.

KATA KUNCI: obesitas, jaringan lemak perivaskular, PVAT, penyakit kardiometabolik, adipokin

\section{Introduction}

The high prevalence of obesity throughout the world has increasingly focused on the association between body weight, cardiovascular risk factors and clinical cardiovascular disease.(1) Body fat distribution may be more strongly associated with obesity-related comorbidities and cardiovascular disease compared with generalized measures of adiposity, such as body mass index (BMI).(2-5)

In humans and most animal models, the development of obesity leads not only to increased fat depots in classical adipose tissue locations but also to significant lipid deposits within and around other tissues and organs, a phenomenon known as ectopic fat storage. Ectopic fat, defined as the deposition of fat in non-classical locations including the heart, kidneys and blood vessels, may contribute to the development of cardiovascular disease by exerting a local toxic effect on adjacent structures.(6-8) One such ectopic fat depot is perivascular adipose tissue (PVAT), which is directly adherent to blood vessels. PVAT includes fat surrounding large arteries, as well as organ-specific fat depots in which adipose tissue surrounds the organ's vasculature. Periaortic fat falls into the former category, whereas epicardial, pericardial and perirenal fat fall into the latter category.(9)

PVAT has been shown to produce a variety of adipokines that contribute to regulation of vascular tone and local inflammation. Signaling from PVAT to the vasculature ("vasocrine" signaling) may not only cause vascular disease associated with obesity, but also reduce insulin-induced glucose disposal by reducing muscle perfusion. In recent years, evidence has emerged suggesting that this PVAT may hold one of the keys to effective future treatment or prevention of both insulin resistance and cardiovascular disease in obesity.(10)

\section{Adipose Tissue and Adipokine in Obesity}

Obesity is an ongoing worldwide epidemic. Besides being a medical condition in itself, obesity dramatically increases the risk of development of metabolic and cardiovascular disease. This risk appears to stem from multiple abnormalities in adipose tissue function leading to a chronic inflammatory state and to dysregulation of the endocrine and paracrine actions of adipocyte-derived factors. These, in turn, disrupt vascular homeostasis by causing an imbalance between the nitric oxide (NO) pathway and the endothelin-1 system, with impaired insulin-stimulated endothelium-dependent vasodilation.(11)

It is now well established that adipose tissue is not only involved in energy storage but also functions as an endocrine organ that secretes various bioactive substances. $(12,13)$ The dysregulated expression of these factors, caused by excess adiposity and adipocyte dysfunction, has been linked to the pathogenesis of various disease processes through altered immune responses.(14)

The expression of adipokines can also vary depending on the site of an adipose tissue depot (Figure 1). The two most abundant depots are visceral and subcutaneous adipose tissues, which produce unique profiles of adipokines. $(15,16)$ In addition, adipocyte depots occur throughout the body in association with multiple organs, including the heart and kidneys. Adipocytes are also found in the bone marrow, lungs and the adventitia of major blood vessels. In some instances, it has been shown that high-calorie diets can promote the development of a pro-inflammatory state in these depots in a similar manner to that observed in subcutaneous and visceral adipose tissue.(17) Although the functional importance of many of these individual adipose depots is generally not known, recent evidence suggests that diet-induced changes in their adipokine secretion can influence the function of the associated tissue.(18)

Accumulating evidence indicates that a state of chronic inflammation has a crucial role in the pathogenesis of obesity-related metabolic dysfunction.(19,20) Indeed, clinical and epidemiological studies have described a clear connection between the development of low-grade inflammatory responses and metabolic diseases, particularly in the context of obesity and type 2 diabetes. Excess adipose mass (as occurs in obese individuals) is associated with increased levels of the pro-inflammatory marker C-reactive 
protein (CRP) in the blood.(21) Increased levels of CRP, and its inducer interleukin-6 (IL-6), are predictive of the development of type 2 diabetes in various populations. $(21,22)$

The adipose tissue provides vital information about its own mass and the whole body's nutritional status to the brain and to insulin-sensitive organs and tissues through the synthesis and secretion of a number of adipokines such as leptin, adiponectin and resistin. $(23,24)$ Leptin participates in the physiological regulation of appetite, by signalling the level of satiety to the brain.(25) Paradoxically, the majority of obese individuals have elevated circulating leptin levels, likely secondary to leptin resistance.(26) Furthermore, high leptin concentrations correlate with adverse cardiovascular outcomes in obese patients.(27)

Adiponectin is an adipocyte-derived peptide that circulates in high concentrations in plasma(28) and whose actions include enhancement of insulin-mediated glucose uptake in skeletal muscle, suppression of hepatic glucose production and amelioration of insulin resistance.(29) Adiponectin's concentrations, unlike most of the other adipokines, are inversely correlated with BMI(30) and visceral fat(31), and are reduced in patients with obesity and type 2 diabetes(32).

Adiponectin is one of the few adipokines that possesses multiple salutary effects on insulin sensitivity and cardiovascular health. Clinical investigations have identified adiponectin deficiency (hypoadiponectinaemia) as an independent risk factor for cardiovascular disease (CVD). In animals, elevation of plasma adiponectin by either pharmacological or genetic approaches alleviates obesityinduced endothelial dysfunction and hypertension, and also prevents atherosclerosis, myocardial infarction and diabetic cardiomyopathy. Adiponectin protects cardiovascular health through its vasodilator, anti-apoptotic, anti-inflammatory and anti-oxidative activities in both cardiac and vascular cells.(33)

Resistin, an adipocyte-specific peptide in rodents, in humans is mainly produced by macrophages. It has been suggested that resistin may play a role in the development of insulin resistance and obesity(34) and that its levels may be increased in patients with type 1 and 2 diabetes(35). Evidence suggests that resistin is involved in pathological processes leading to CVD including inflammation, endothelial dysfunction, thrombosis, angiogenesis and smooth muscle cell dysfunction.(36)

Resistin possibly binds to the membrane bound toll-like receptor 4, which then activates the intracellular signalling pathway. Resistin can activate the translocation of nuclear factor (NF)КB into the nucleus, which in turn, activates the transcription of pro-inflammatory cytokine genes, contributing to the proliferation of vascular smooth muscle cells (VSMCs) and endothelial dysfunction. Activation of NFKB can also be mediated by the resistininduced activation of phosphatidylinositol 3-kinase / Akt pathway. Resistin can also stimulate the production of pro-inflammatory cytokines through mitogen-activated protein kinase (MAPK) p38 and c-Jun N-terminal kinase. Resistin can cause oxidative stress, which is another factor for MAPK activation and endothelial NO synthase (eNOS) inhibition. Resistin increases the production of superoxide anions $\left(\mathrm{O}_{2}^{-}\right)$, which inhibit eNOS gene expression and reduce bioavailability of NO. VSMCs proliferation and endothelial dysfunction including impaired vasorelaxation,

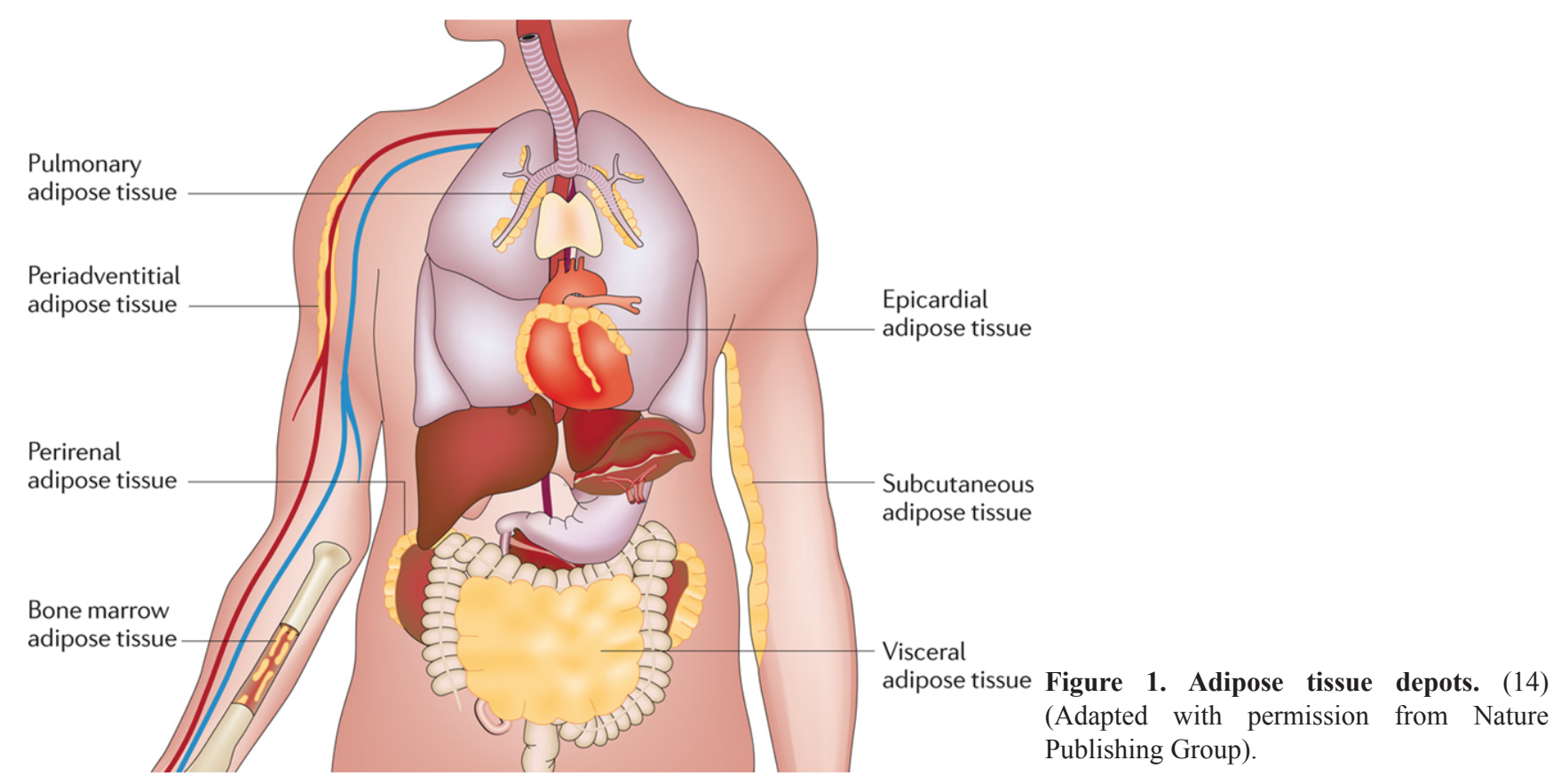


enhanced thrombosis, hyperpermeability, angiogenesis and increased cell adhesion collectively contribute to the formation of atherosclerosis.(36)

A group of adipokines, including adipocyte fatty acid binding protein (A-FABP) and lipocalin-2, possess specific lipid-binding activity and are up-regulated in obese human subjects and animal models. They act as lipid chaperones to promote lipotoxicity in endothelial cells and cause endothelial dysfunction under obese conditions. However, different small lipid-binding proteins modulate the development of vascular complications in distinctive manners, which are partly attributed to their specialized structural features and functionalities.(37)

Several recent studies indicate that adipokines, such as leptin, resistin, IL-6 and tumor necrosis factor (TNF) $\alpha$ exert adverse effects on vasodilator function in animals with experimental obesity. These effects in part are mediated by elevated reactive oxygen species (ROS) production in the vascular wall. In obesity, during expansion of adipose tissue phenotypic changes of adipocytes occurs, which results in increased production of leptin, resistin, TNF $\alpha$ and IL-6. In addition to their systemic actions, these adipokines may locally induce production of $\mathrm{O}_{2}^{-}$in the adipose tissue arteriole. $\mathrm{O}_{2}^{-}$interferes with the availability of NO and reduces dilator function of microvessels. Altered microvascular responsiveness may provoke hypoxia in the expanded adipose tissue, which via hypoxia inducible factor (HIF) $1 \alpha$ would exaggerate pathological changes in adipokine production. Adipocytes may also enhance monocyte chemotactic protein 1 (MCP1) synthesis, which facilitates macrophage accumulation and activation, to maintain oxidative stress and adipose tissue inflammation. (38)

Obesity results in an imbalance between endotheliumderived vasoactive factors favouring vasoconstriction, cell growth and inflammatory activation. Abnormal regulation of these factors due to endothelial cell dysfunction is both a consequence and a cause of vascular disease processes. Because of the similarities of the vascular pathomechanisms activated, obesity can be considered to cause accelerated, 'premature' vascular aging.(39)

\section{Ectopic Fat Storage in Heart and Blood Veseel}

In humans and most animal models, the development of obesity leads not only to increased fat depots in classical adipose tissue locations but also to significant lipid deposits within and around other tissues and organs (ectopic fat storage). With fat gain, lipid deposition can impair tissue and organ function in two possible ways. First, the size of fat pads around key organs may increase substantially. This could modify organ function either by simple physical compression or because peri-organ fat cells may secrete various locally acting substances. Second, lipid accumulation can occur in non-adipose cells and may lead to cell dysfunction or cell death, a phenomenon known as lipotoxicity. $(6,40,41)$

Throughout the body, most arteries and veins with a diameter greater than $100 \mu \mathrm{m}$ are in contact with/surrounded by adipocytes. The term "perivascular adipose tissue" refers to adipose tissue around vessels, irrespective of location. Known locations of PVAT include the coronaries (epicardial adipose tissue)(42), aorta (periaortic adipose tissue)(43), and the microvascular beds of the mesentery(44), muscle(45), kidney(6), and adipose tissue(46).

PVAT consists of adipocytes, fibroblasts, stem cells(47), mast cells(48,49), and nerves(48). PVAT is initially formed in the embryological phase and remains in place throughout life; in times of nutrient abundance and obesity, PVAT expands and undergoes an inflammatory transformation. The volume of PVAT is associated with the quantity of intra-abdominal adipose tissue(50,51). Accumulating evidence suggests that the products of PVAT (ie, adipokines) contribute to regulation of vascular function. In this regard, both protective physiologic and pathologic properties of PVAT have been proposed(10).

\section{Ectopic fat storage in the heart}

Most animal models of obesity as well as obese humans show an increased cardiac mass. In the rabbit model of obesity, a $50 \%$ gain in body weight led to an increase in dry weight of the right and left ventricles by about 70 and $50 \%$, respectively, and to an increase in protein content by about $50 \%$ in both right and left ventricles.(52) Overall, those changes led to significant alterations in cardiac function. To what extent the cardiac changes observed in obesity are due to ectopic fat storage is not clear. In fact, the combination of a mild increase in blood pressure, increase in cardiac output, increase in the heart rate-pressure product, and ectopic fat storage within and around the heart, could have additive effects resulting in the frequent observation of systolic and diastolic dysfunctions in obesity, which in the long term promote heart failure.(6)

\section{Ectopic fat storage around blood vessels}

Nearly, all blood vessels in the body are surrounded by variable amounts of adventitial fat. Traditionally, perivascular fat has been assumed to serve as structural support for the vasculature. However, perivascular fat 
has been shown to modulate vascular responsiveness to vasoactive agents in studies of the aorta $(53,54)$ and of the mesenteric vessels(44). Interestingly, diet-induced fat deposition in experimental models of obesity is not limited to the subcutaneous fat and to the classical visceral depots in tight connection with mediastinic and abdominal organs, but also occurs along the major blood vessels.(55) The pathophysiological consequences of increased perivascular fat in obesity could simply be mechanical. As more adipose tissue wraps around blood vessels, it is conceivable that the large amounts of perivascular fat could contribute to the increased vascular stiffness often observed in obese subjects. Excess body weight is associated with higher aortic stiffness as determined by magnetic resonance imaging techniques (56) or by aortic pulse wave velocity measurements.(57) What is worrisome is that the strength of this association can be seen in very young adults.(57) In fact, noninvasive measurements of the carotid artery by ultrasound imaging in severely obese children revealed a significantly greater carotid stiffness.(58) In addition, perivascular fat could act as a secretory organ to influence the neighboring blood vessels. This function of perivascular fat is very intriguing since studies in isolated blood vessels have shown that the contractile response of rat aortic rings to angiotensin II, serotonin and phenylephrine was significantly attenuated in the presence of periadventitial fat.(54)

\section{Ectopic fat storage in the kidney}

The development of obesity-induced hypertension in $\operatorname{dogs}(59)$ and rabbits(60) is associated with significant sodium retention in spite of a marked increase in GFR. Analysis of renal artery pressure-sodium excretion relationship in obese dogs fed an HFD for 5-6 weeks reveals a shift to the right as well as a decrease of the slope of the pressure-natriuresis curve.(61) Many mechanisms(62) have been suggested to explain this abnormal sodium handling, including increased renal nerve sympathetic activity, activation of the renin-angiotensin-aldosterone system, as well as direct sodium-retaining effects of insulin. In addition, there is evidence that weight gain is associated with abnormal physical forces within the kidney that could promote sodium retention.(63) The mechanisms by which weight-gain leads to abnormal intrarenal physical forces are complex, but could be related to the marked structural renal changes observed in animal models of diet-induced obesity (dogs, rabbits). Accumulation of fat in the renal sinus (sinus lipomatosis) may favor compression of the renal inner medulla and of hilum structures.(6) Taken together, ectopic fat storage in key target-organs of cardiovascular control may impair their functions, contributing to the increased prevalence of cardiovascular diseases in obese subjects.

\section{PVAT as Regulator of Vascular Function}

Fifty years ago, the vision of vascular control was rather simple: besides local metabolites directly governing the opening of arterioles in function of the needs of the tissues, daily vascular regulation was pretty much the affair of the omnipotent sympathetic adrenergic nervous system. A first glimpse of the importance of local modulation of the control of vascular tone came with the realization that a number of factors could impinge on the adrenergic nerve endings and reduce or augment the amount of noradrenaline released per nerve impulse reaching the adrenergic varicosities.(64)

A further fundamental breakthrough was the discovery that endothelial cells could initiate relaxations(65) or contractions(66) of the underlying vascular smooth muscle, permitting the concept of endothelium-dependent control of vascular tone. $(67,68)$ Thirty years later we know a lot about nitric oxide, endothelium-dependent hyperpolarization, endothelins and endothelium-derived vasoconstrictor prostaglandins but we still do not understand all the complexities of endothelial control.(69-75)

Both in the animal and in humans, obesity results in progressive endothelial dysfunction, not only in large arteries, but also at the level of the microcirculation, which then helps us to understand why it is a major risk factor for cardiovascular disease.(11,28,38,39) Obesity has detrimental effects on the microcirculation. Functional changes in microvascular responsiveness may increase the risk of developing cardiovascular complications in obese patients. Emerging evidence indicates that selective therapeutic targeting of the microvessels may prevent lifethreatening obesity-related vascular complications, such as ischaemic heart disease, heart failure and hypertension. It is also plausible that alterations in adipose tissue microcirculation contribute to the development of obesity. (38)

Although most of the systemic arteries except the cerebral vasculature are surrounded by PVAT, the functional role of PVAT other than as a structural support of the blood vessel has long been neglected. Recent studies, however, indicate a crucial role of PVAT not only in the regulation of blood vessel function but also in its structure.(76) PVAT secretes more pro-inflammatory cytokines such as IL-6, IL-8 and MCP-1 than subcutaneous adipose tissue.(17) Because PVAT encroaches into the adventitia without an anatomical barrier, it is suggested that humoral factors secreted by PVAT easily access the blood vessel wall, indicating that PVAT functions as a paracrine organ that transduces metabolic signals to blood vessels.

Today's paradigm holds that the vascular wall consists 
of 3 layers: the tunicae intima, media, and adventitia. Chalkadov et al. suggest that PVAT may indeed be considered the fourth, outermost vascular layer, that is, tunica adiposa. Because there is a lack of any fascia-like structure between the adventitia and the PVAT.(77,78) PVAT is a producer of a large number of bioactive molecules such as adipokines(77-80), which, in a paracrine way, may exert proinflammatory and smooth muscle cell growth/migration promoting, in fact, atherogenic effects(79) and PVAT releases vasorelaxing factor(s)(81), which may benefit the vascular biology, hence, a question whether PVAT is an enemy or a friend of the artery may emerge (82).

Recent in vitro and in vivo evidence identifies adipose tissue as a critical endocrine organ that secretes a variety of bioactive signalling molecules into the circulation. These molecules include vascular endothelial growth factor (VEGF), IL-6, IL-1, TNF $\alpha$, leptin, adiponectin (ACRP30), resistin, omentin, acylation stimulation protein (ASP), apelin, adipsin, agouti, insulin-like growth factor (IGF-1), angiotensinogen, plasminogen activator protein (PAI-1), ROS and sex steroids.(83-85) These substances can play an autocrine role in the regulation of adipocyte metabolism. Upon secretion into the bloodstream, they can also play an endocrine role in the regulation of other cellular processes, including vascular function and peripheral resistance.

Although adiponectin has been reported to relax aortic and mesenteric artery by opening voltage-dependent $\mathrm{K}^{+}(\mathrm{Kv})$ channels $(46,86)$, adiponectin is not an adipocytederived relaxing factor because the anti-contractile effects of PVAT are preserved in adiponectin-deficient mice(86). Intriguingly, PVAT enhances the arterial contractile response to perivascular nerve stimulation through NADPH oxidasemediated superoxide production.(87) Therefore, PVAT from normal animals has a dual role in the regulation of blood

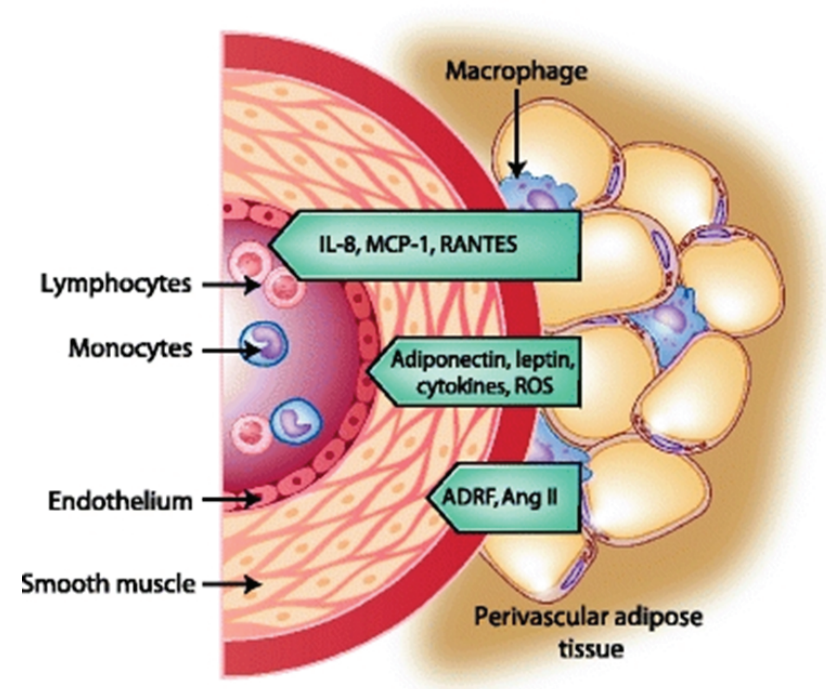

vessel contraction.

Lohn et al. described in 2002 the so-called "adventitium-derived relaxing factor" (ADRF), which was shown to be produced by isolated adipocytes and diminished the contractile response of intact aortic rings to serotonin, angiotensin II, or phenylephrine.(54) They suggested that PVAT release a transferable ADRF that acts by tyrosine kinase-dependent activation of potassium channels in vascular smooth muscle cells. The molecular nature of ADRF is still unknown; however, its presence has been confirmed in small mesenteric arteries.(88) ADRF acts independently of leptin receptors; however, leptin itself was also able to diminish angiotensin II-induced vasoconstriction by leptin receptor-mediated inhibition of intracellular calcium increase in smooth muscle cells of the rat aorta.(89)

Result from study by Fesus et al., demonstrated that the anti-contractile effects of perivascular fat occur through access of ADRF from outside the vessel ('outside control'). (86) The possible contribution by perivascular adipocytes to the regulation of vascular tone and to vascular remodeling appears to be especially important because of the current obesity epidemic that has resulted in increased numbers of diabetic and hypertensive patients. If perivascular adipocytes react like adipocytes in other depots, a dysregulation of the secretion of vasoactive and proinflammatory molecules can then be expected.(90)

Recent studies explored the possibility that ADRF might be a volatile, gaseous mediator that disappears into the atmosphere during purification.(91) Previously, studies demonstrated that NO is not ADRF. $(44,54)$ The possibility that ADRF might be another biological active gaseous mediator, such as $\mathrm{H}_{2} \mathrm{~S}$ or carbon monoxide $(\mathrm{CO}) . \mathrm{H}_{2} \mathrm{~S}$ is a newly discovered physiologic vasorelaxant generated by cystathionine gamma lyase (CSE).(92) This enzyme is expressed in PVAT and endogenously generates $\mathrm{H}_{2} \mathrm{~S}$.(93)

Fang et al. obtained similar results with CSE inhibitors in the rat aorta. In an elegant series of experiments, they measured endogenous $\mathrm{H}_{2} \mathrm{~S}$ production in the aorta and found that serotonin, phenylephrine and angiotensin II increase $\mathrm{H}_{2} \mathrm{~S}$ release from PVAT. Release of $\mathrm{H}_{2} \mathrm{~S}$ is decreased with aging of rats and can be blocked by CSE inhibitors. (94) Nonetheless, the data indicate that $\mathrm{H} 2 \mathrm{~S}$ represents a candidate or modulator of ADRF.

ADRF is released by visceral periadventitial adipocytes and primarily produces endotheliumindependent vasorelaxation by opening $\mathrm{Kv}$ channels

Figure 2. Interaction of PVAT with vascular endothelium, smooth muscle, and immune cells and the mediators involved.(10) (Adapted with permission from Springer). 


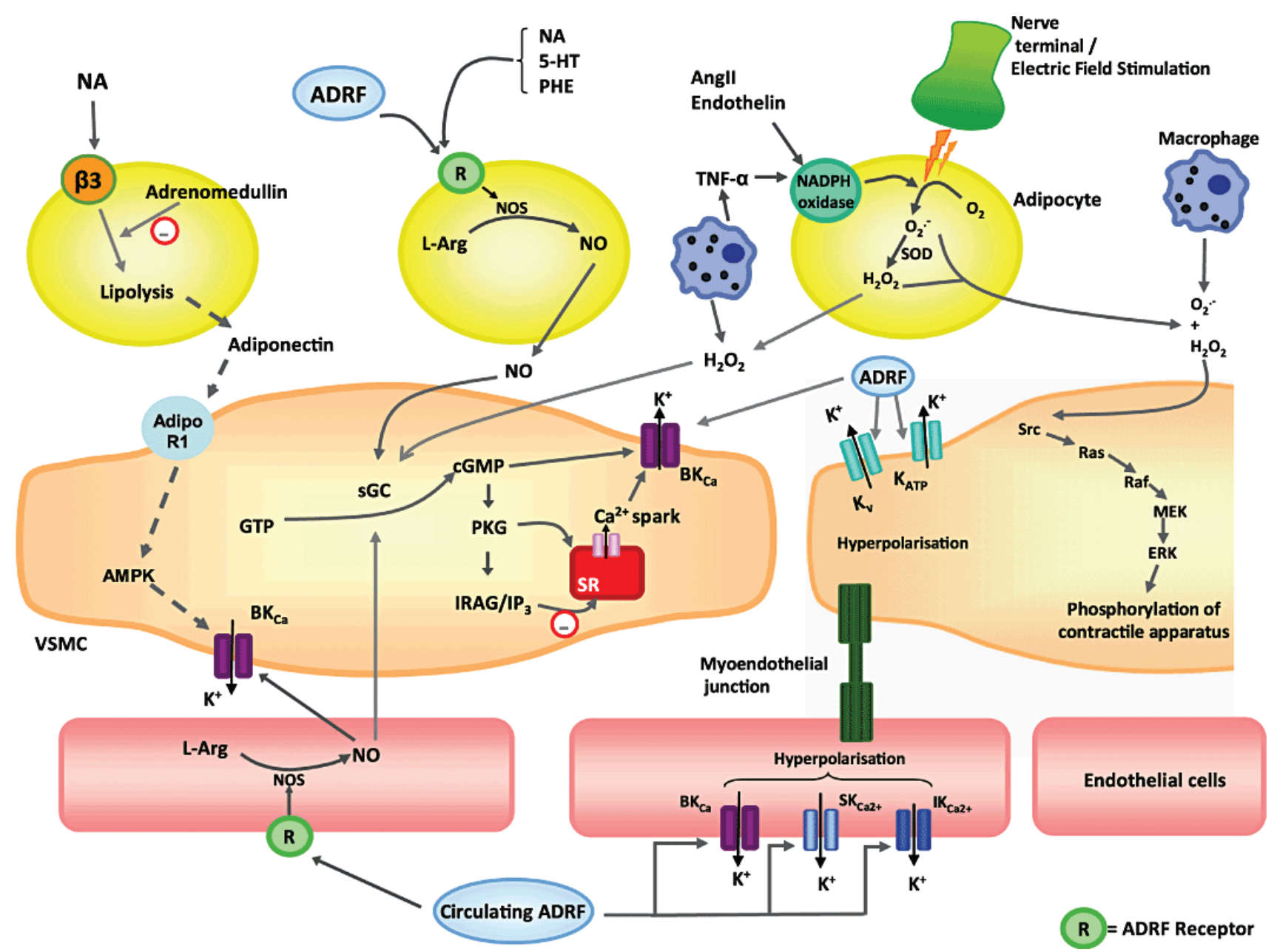

Figure 3. Potential mechanisms via which perivascular adipocytes, vascular smooth muscle cells and endothelial cells interact.(98) (Adapted with permission from Wiley and Sons, Inc.).

in the plasma membrane of smooth muscle cells.(95) Kv7 family of potassium (KCNQ) channels exhibit a large hyperpolarisation reserve and are enabled to fulfil physiological vasodilatory functions in the presence of perivascular fat, i.e. in response to ADRF. Moreover, since $\mathrm{ADRF}$ is released from perivascular adipocytes, KCNQ channels seem to play a unique role for vasodilatory signals from outside the vessel ('outside control'). KCNQ channels are not targeted by endothelium- derived relaxing factors (EDRF) ('inside control'), including NO, prostaglandin I2 (prostacyclin) and endothelium-derived hyperpolarizing factor (EDHF).(95) KCNQ channels are also not targeted by other perivascular candidates, such as $\mathrm{H}_{2} \mathrm{O}_{2}$, superoxide and Angiotensin 1-7. The data support the novel concept that ADRF $\mathrm{H}_{2} \mathrm{~S}$ is the physiological activator of KCNQ channels, at least in part, in visceral arteries.

The dilator effect of PVAT in patients with obesity and metabolic syndrome is lost.(46) The obese phenotype of PVAT could be mimicked by addition of inflammatory cytokines such as TNF $\alpha$ or IL- 6 to healthy PVAT, confirming a pivotal role of adipokines in blood vessel dysfunction. This study also showed that hypoxia resulted in the loss of the anti-contractile effect of healthy PVAT. This makes sense because accumulation of lipid and infiltration of inflammatory cells into the PVAT may cause hypoxia, and hypoxia is known to induce oxidative stress and cytokine production.(96)

The PVAT of obese patients may cause structural remodeling of the blood vessel. The thickness including adventitia and PVAT in the carotid artery is increased in patients with diabetes and dyslipidemia, and the thickness is correlated with intima-media thickness of the carotid artery. (97)

\section{PVAT and Cardiometabolic Diseases}

Atherosclerosis is traditionally viewed as a disease of the vascular intima, following a paradigm of endothelial cell dysfunction, inflammatory cell recruitment, and foam cell formation.(98-102) More recently, dysfunction of medial smooth muscle cells and adventitial cells has also been demonstrated to play a role in the pathogenesis of atherosclerosis. $(103,104)$ Recent evidence indicates that the 
periadventitial adipose depot is a functional component of the vasculature, exerting paracrine influences on blood vessel contractility. $(44,54)$ By virtue of their unique functional and biochemical properties, perivascular adipocytes may play a primary role in establishing adventitial inflammation in atherosclerosis.(17)

Obesity is associated with inflammation of adipose tissue $(24,105)$ Much of the evidence demonstrating the association of obesity with adipose inflammation comes from the study of visceral adipose tissue (VAT).(24) However, growing evidence supports a similar process in PVAT.(17,24,42,106) IL-1 $\beta$, IL-6, MCP-1 and TNF $\alpha$ were shown to be higher in obese subjects undergoing bypass surgery in epicardial as opposed to subcutaneous fat.(42). In related studies, in vitro differentiated human perivascular adipocytes demonstrated increased levels of IL-8, IL-6 and MCP-1 compared with subcutaneous adipose tissue.(17)

The recognition that perivascular adipose inflammation potentially contributes to atherosclerosis has led to an 'outside-in' theory of vascular inflammation. Vascular inflammation was already believed to follow an 'insideout' process in which intimal injury leads to expression of vascular adhesion molecules, release of inflammatory signals and subsequent homing of blood-borne immune cells to the endothelium.(107) This intimal inflammation then spreads into the media and adventitia.(108) The 'outsidein' theory postulates that inflammation begins in adipose tissue and then spreads inward to the vasculature.(104) This is supported by the lack of a fascial plane between the adventitia and surrounding adipose tissue, as well as the extension of the vasa vasorum into PVAT.(82) Consistent with this, immunostaining of atherosclerotic human aortas has shown the presence of inflammatory cells at the junction of PVAT and the vascular adventitia. $(9,106)$

The use of imaging modalities to quantitatively assess the amount of PVAT in specific perivascular fat depots has been fundamental to the epidemiological study of obesity and vascular disease. To date, most imaging of PVAT has focused on pericardial fat, which can be measured by ultrasound, multidetector computed tomography (MDCT) and MRI.(7,109-111). More recently, a reliable method for the assessment of periaortic fat volume has been developed. (112)

The associations of epicardial and pericardial fat with metabolic risk factors, indices of myocardial structure and function and clinical vascular disease have been assessed in epidemiological studies. These studies have used multiple imaging modalities, and the terminology differs depending on the technique used. Echocardiographic studies generally use the term 'epicardial fat', whereas MDCT studies generally use the term 'pericardial fat'.(7,113) Epicardial fat is defined anatomically as the fat located between the myocardium and visceral pericardium. Pericardial fat has been defined by MDCT in two ways. The first definition, used by the FHS, includes any fat located within the pericardial sac. The second definition of pericardial fat, used by the Multi-Ethnic Study of Atherosclerosis (MESA) and the Jackson Heart Study (JHS), includes both epicardial fat and paracardial fat. Paracardial fat includes fat covering the parietal pericardium.(9)

Current research on perivascular fat opens a new field in vascular biology. Both the intimal endothelium and the adventitial fat regulate contraction and growth of medial VSMCs.(114) The crosstalk between cells in the blood vessel wall is vital for normal vascular function. Imbalance of PVAT-derived factors may play a role in proliferative vascular diseases such as atherosclerosis, restenosis and hypertension. To identify key factors altered in distinct sites of PVAT and involved in stimulation of proliferation may help to develop new therapies for the prevention and treatment of vascular disease.

PVAT is significantly correlated with most cardiometabolic risk factors and coronary artery calcification (CAC) in the JHS cohort. The results suggest that PVAT is an important VAT depot that may exert a local effect on the coronary vasculature.(115) Preservation of PVAT may be as important as preservation of endothelium for a successful vascular intervention.

Yudkin et al. originally postulated that PVAT might hold the key to linking obesity with the development of metabolic syndrome and diabetes as a result of an adverse influence upon the vasculature.(45) In health, PVAT could produce adipokines that profoundly influence metabolism and the control of local vascular tone via vasocrine actions. It was suggested that the loss of such substances would result in a change in vascular function and development of insulin resistance.(98)

As mentioned above, vascular function and especially microvascular blood volume in muscle are related to insulin sensitivity. Because obesity is associated with insulin resistance, reduction of microvascular blood volume, and altered properties of PVAT, we have proposed that PVAT causes microvascular dysfunction and insulin resistance in obesity.(45) Although there are, at present, no studies that prospectively link PVAT to diabetes, a number of studies provide indirect evidence for this hypothesis.(10)

First, several studies suggest that ectopic adipose tissue, especially within muscles, strongly relates to insulin sensitivity. The amount of PVAT surrounding the brachial artery(51) and adipose tissue between muscle (intermuscular adipose tissue (IMAT))(116) are inversely related to insulin sensitivity. Even though IMAT accounts for only $3 \%$ of total 


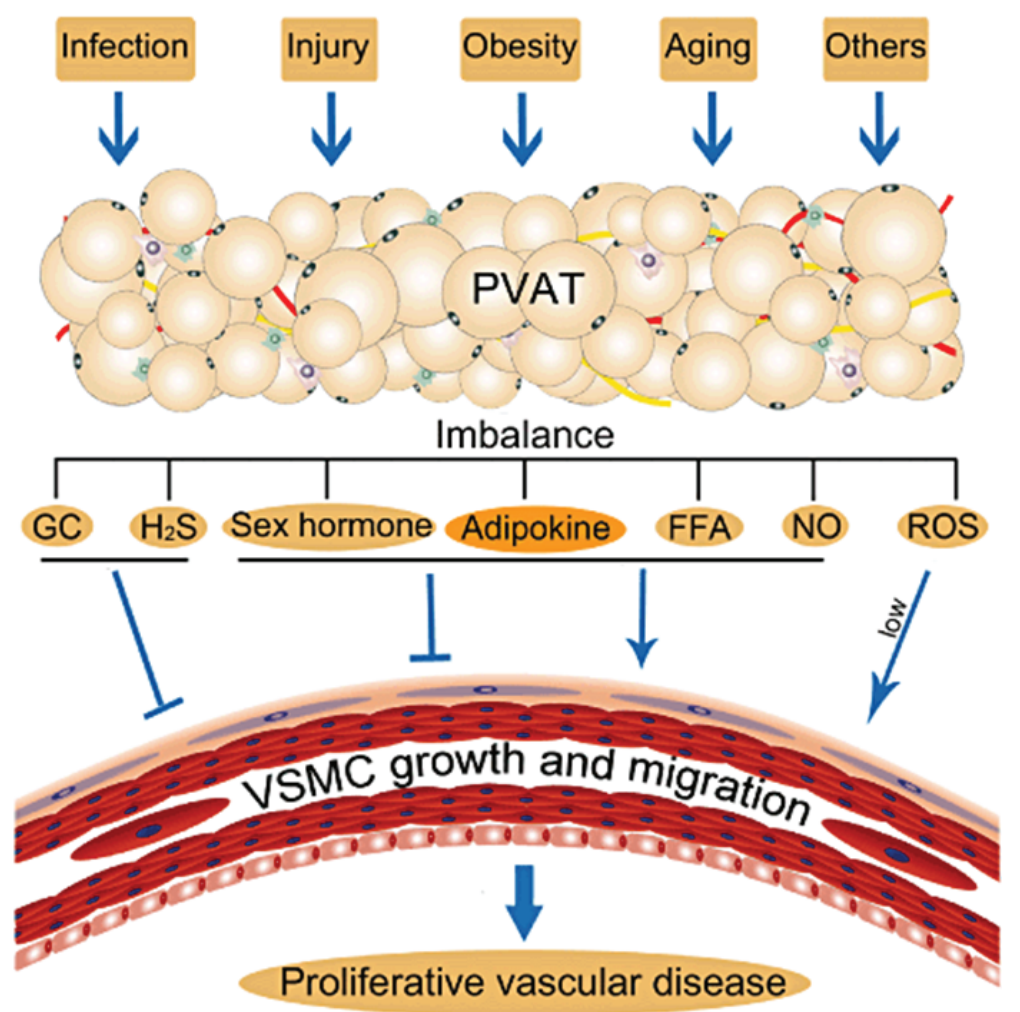

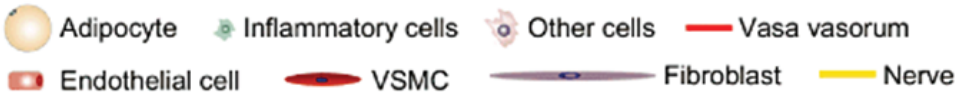

Figure 4. Schematic diagram for perivascular fat dysfunction and vascular disease. (114) (Adapted with permission from Wiley and Sons, Inc.). thigh adipose tissue, it has the strongest correlation with insulin sensitivity in obese subjects and subjects with type 2 diabetes mellitus.

Second, vascular function, especially muscle perfusion, contributes to regulation of insulin-mediated glucose disposal. Increased amounts of adipose tissue, as observed in obese subjects and rats, are accompanied by impairment of muscle perfusion. Impairment of muscle perfusion has been estimated to account for $30 \%$ to $50 \%$ of insulin resistance.(117)

Third, accumulation of PVAT around the arterioles that regulate muscle perfusion. Aside from intermuscular adipose tissue and PVAT around the femoral artery, we have found that PVAT exists within muscles (ie, intramuscular PVAT (mPVAT)). This location is especially relevant given the increasing evidence for regulation of muscle insulin sensitivity by microvascular perfusion in muscle. $(117,118)$ By regulating endothelium-dependent vasodilatation, insulin-mediated vasoreactivity, and muscle perfusion, mPVAT may control muscle glucose uptake and, thus, determine risk of future type 2 diabetes.(10)

The mechanisms controlling the quantity of PVAT and adipokine secretion from PVAT remain to be determined. Because PVAT is related to insulin resistance, controls vascular function, and is located within insulin target tissues, it may well contribute to the pathogenesis of type 2 diabetes as well as cardiovascular disease.(10)

In summary, PVAT is in close connection with the media of blood vessels, separated from it only by a very thin adventitial layer. The mass of perivascular fat increases in obesity and it is postulated that a paracrine secretion of various growth-stimulating and proinflammatory agents could contribute to the pathogenesis of cardiovascular diseases (6). PVAT is increasingly recognized as a widespread, relevant tissue in vascular biology and important determinant of cardiometabolic complications of obesity.

\section{Conclusion}

Adipose tissue is an active endocrine and paracrine organ that may influence the development of atherosclerosis and vascular disease. In the setting of obesity, adipose tissue produces a variety of inflammatory cytokines (or adipokines) that are known to modulate key mechanisms of atherogenesis. In particular, adipose tissue located on the surface of the heart surrounding large coronary arteries (i.e. epicardial PVAT) has been implicated in the pathogenesis of coronary artery disease. The organism's perivascular adipocytes act as an integrated organ responsible for 
paracrine and vasocrine signalling, which in turn contributes to skeletal muscle insulin resistance.

The pathophysiology of PVAT in obesity and its influence on oxidative stress, inflammation, insulin resistance, endothelial dysfunction and vascular reactivity is well established. In addition, the contribution of specific epicardial perivascular adipose-derived adipokines (e.g. leptin, adiponectin) to the initiation and expansion of coronary disease is also evidenced. Future investigative with an emphasis on indentifying novel therapeutic targets and disease markers within PVAT are promising.

\section{References}

1. Caterson ID, Hubbard V, Bray GA, Grunstein R, Hansen BC, Hong $\mathrm{Y}$, et al. Prevention Conference VII: Obesity, a worldwide epidemic related to heart disease and stroke: Group III: worldwide comorbidities of obesity. Circulation. 2004; 110: E476-83.

2. Canoy D. Distribution of body fat and risk of coronary heart disease in men and women. Curr Opin Cardiol. 2008; 23: 591-8.

3. Fox CS, Massaro JM, Hoffmann U, Pou KM, Maurovich-Horvat $\mathrm{P}$, Liu CY, et al. Abdominal visceral and subcutaneous adipose tissue compartments: association with metabolic risk factors in the Framingham Heart Study. Circulation. 2007; 116: 39-48.

4. Mahabadi AA, Massaro JM, Rosito GA, Levy D, Murabito JM, Wolf $\mathrm{PA}$, et al. Association of pericardial fat, intrathoracic fat, and visceral abdominal fat with cardiovascular disease burden: the Framingham Heart Study. Eur Heart J. 2009; 30: 850-6.

5. Wang Y, Rimm EB, Stampfer MJ, Willett WC, Hu FB. Comparison of abdominal adiposity and overall obesity in predicting risk of Type 2 diabetes among men. Am J Clin Nutr. 2005; 81: 555- 63.

6. Montani JP, Carroll JF, Dwyer TM, Antic V, Yang Z, Dulloo AG. Ectopic fat storage in heart, blood vessels and kidneys in the pathogenesis of cardiovascular diseases. Int J Obes Relat Metab Disord. 2004; 28: S58-65.

7. Rosito GA, Massaro JM, Hoffmann U, Ruberg FL, Mahabadi AA, Vasan RS, et al. Pericardial fat, visceral abdominal fat, cardiovascular disease risk factors, and vascular calcification in a communitybased sample: the Framingham Heart Study. Circulation. 2008; 117: 605-13.

8. Lehman SJ, Massaro JM, Schlett CL, O’Donnell CJ, Hoffmann U, Fox CS. Peri-aortic fat, cardiovascular disease risk factors, and aortic calcification: the Framingham Heart Study. Atherosclerosis. 2010; 210: 656-61.

9. Britton KA, Fox CS. Perivascular adipose tissue and vascular disease. Clin Lipidol. 2011; 6: 79 - 91.

10. Meijey RI, Serne EH, Smulders YM, van Hinsbergh VWM, Yudkin JS, Eringa EC. Perivascular Adipose Tissue and Its Role in Type 2 Diabetes and Cardiovascular Disease. Curr Diab Rep. 2011; 11: 211-7.

11. Campia U, Tesauro M, Cardillo C. Human Obesity and endothelium dependent responsiveness. Br J Pharmacol. 2011; 165: 561 - 73.

12. Ouchi N, Kihara S, Funahashi T, Matsuzawa Y, Walsh K. Obesity, adiponectin and vascular inflammatory disease. Curr Opin Lipidol. 2003; 14: 561-6.

13. Berg AH, Scherer PE. Adipose tissue, inflammation, and cardiovascular disease. Circ Res. 2005; 96: 939-49.

14. Ouchi N, Parker JL, Lugus JJ, Walsh K. Adipokines in inflammation and metabolic disease. Nat Rev Immunol. 2011; 11: 85 - 97.
15. Samaras K, Botelho NK, Chisholm DJ, Lord RV. Subcutaneous and visceral adipose tissue gene expression of serum adipokines that predict type 2 diabetes. Obesity. 2010; 18: 884-9.

16. Fried SK, Bunkin DA, Greenberg AS. Omental and subcutaneous adipose tissues of obese subjects release interleukin-6: depot difference and regulation by glucocorticoid. J Clin Endocrinol Metab. 1998; 83: 847-50.

17. Chatterjee TK, Stoll LL, Denning GM, Harrelson A, Blomkalns AL, Idelman G, et al. Proinflammatory phenotype of perivascular adipocytes: influence of high-fat feeding. Circ Res. 2009; 104: 5419.

18. Chatterjee TK, Stoll LL, Denning GM, Harrelson A, Blomkalns AL, Idelman G, et al. Periadventitial adipose tissue plays a critical role in vascular remodeling. Circ Res. 2009; 105: 906-11.

19. Hotamisligil GS. Inflammation and metabolic disorders. Nature. 2006; 444: 860-7.

20. Shoelson SE, Lee J, Goldfine AB. Inflammation and insulin resistance. J Clin Invest. 2006; 116: 1793-801.

21. Visser M, Bouter LM, McQuillan GM, Wener MH, Harris TB. Elevated $\mathrm{C}$-reactive protein levels in overweight and obese adults. JAMA. 1999; 282: 2131-5.

22. Pradhan AD, Manson JE, Rifai N, Buring JE. Ridker PM. C-reactive protein, interleukin 6 , and risk of developing type 2 diabetes mellitus. JAMA. 2001; 286: 327-34.

23. Lee DE, Kehlenbrink S, Lee H, Hawkins M, Yudkin JS. Getting the message across: mechanisms of physiological cross talk by adipose tissue. Am J Physiol Endocrinol Metab. 2009; 296: E1210-9.

24. Galic S, Oakhill JS, Steinberg GR. Adipose tissue as an endocrine organ. Mol Cell Endocrinol. 2010; 316: 129-39.

25. Ahima RS, Flier JS. Leptin. Annu Rev Physiol. 2000; 62: 413-7.

26. Martin SS, Qasim A, Reilly MP. Leptin resistance: a possible interface of inflammation and metabolism in obesity-related cardiovascular disease. J Am Coll Cardiol. 2008; 52: 1201-10.

27. Sweeney G. Cardiovascular effects of leptin. Nat Rev Cardiol. 2010; 7: 22-9.

28. Hui X, Lam KSL, Vanhoutte PM, Xu A. Adiponectin and cardiovascular health: an update. Br J Pharmacol. 2012; 165: 574.

29. Chiarugi P, Fiaschi T. Adiponectin in health and diseases: from metabolic syndrome to tissue regeneration. Expert Opin Ther Targets. 2010; 14: 193-206.

30. Yamauchi T, Kamon J, Minokoshi Y, Ito Y, Waki H, Uchida S et al. Adiponectin stimulates glucose utilization and fatty-acid oxidation by activating AMP-activated protein kinase. Nat Med. 2002; 8: 1288-95.

31. Matsubara M, Maruoka S, Katayose S. Inverse relationship between plasma adiponectin and leptin concentrations in normal-weight and obese women. Eur J Endocrinol. 2002; 147: 173-80.

32. Lara-Castro C, Luo N, Wallace P, Klein RL, Garvey WT. Adiponectin multimeric complexes and the metabolic syndrome trait cluster. Diabetes. 2006; 55: 249-59.

33. Weyer C, Funahashi T, Tanaka S, Hotta K, Matsuzawa Y, Pratley RE, et al. Hypoadiponectinemia in obesity and type 2 diabetes: close association with insulin resistance and hyperinsulinemia. J Clin Endocrinol Metab. 2001; 86: 1930-5.

34. Lazar MA. Resistin- and Obesity-associated metabolic diseases. Horm Metab Res. 2007; 39: 710-6.

35. Fehmann HC, Heyn J. Plasma resistin levels in patients with type 1 and type 2 diabetes mellitus and in healthy controls. Horm Metab Res. 2006; 34: 671-3.

36. Jamaluddin MS, Weakly SM, Yao Q, Chen C. Resistin: functional roles and therapeutic considerations for vascular disease. Br J Pharmacol. 2012; 165: 622-32.

37. Wang Y. Small lipid-binding proteins in regulating endothelial and cascular functions: focusing on adipocyte fatty acid binging protein 
and lipocalin-2. Br J Pharmacol. 2012; 165: 603-21.

38. Bagi Z, Feher A, Cassuto J. Microvascular responsiveness in obesity: implications for therapeutic intervention. Br J Pharmacol. 2012; 165: 544-60.

39. Barton M, Baretella O, Meyer MR. Obesity and risk of vascular disease: importance of endothelium-dependent vasoconstriction. $\mathrm{Br}$ J Pharmacol. 2012, 165: 591-602.

40. Unger RH, Orci L. Diseases of liporegulation: new perspective on obesity and related disorders. FASEB J. 2001; 15: 312-21.

41. Schaffer JE. Lipotoxicity: when tissues overeat. Curr Opin Lipidol. 2003; 14: 281-7.

42. Mazurek T, Zhang L, Zalewski A, Mannion JD, Diehl JT, Arafat H, et al. Human epicardial adipose tissue is a source of inflammatory mediators. Circulation. 2003; 108: 2460-6.

43. Police SB, Thatcher SE, Charnigo R, Daugherty A, Cassis LA. Obesity promotes inflammation in periaortic adipose tissue and angiotensin II-induced abdominal aortic aneurysm formation. Arterioscler Thromb Vasc Biol. 2009; 29: 1458-64.

44. Verlohren S, Dubrovska G, Tsang SY, Essin K, Luft FC, Huang Y, et al. Visceral periadventitial adipose tissue regulates arterial tone of mesenteric arteries. Hypertension. 2004; 44: 271-6.

45. Yudkin JS, Eringa E, Stehouwer CD. "Vasocrine" signalling from perivascular fat: a mechanism linking insulin resistance to vascular disease. Lancet. 2005; 365: 1817-20.

46. Greenstein AS, Khavandi K, Withers SB, Sonoyama K, Clancy O, Jeziorska $\mathrm{M}$, et al. Local inflammation and hypoxia abolish the protective anticontractile properties of perivascular fat in obese patients. Circulation. 2009; 119: 1661-70.

47. Hu Y, Zhang Z, Torsney E, Afzal AR, Davison F, Metzler B, et al. Abundant progenitor cells in the adventitia contribute to atherosclerosis of vein grafts in ApoE-deficient mice. J Clin Invest. 2004; 113: $1258-65$.

48. Thureson-Klein A, Stijarne L. Ultrastructural features of mast cells in human omental veins. Blood Vessels. 1979; 16: 311-9.

49. Takaoka M, Suzuki H, Shioda S, Sekikawa K, Saito Y, Nagai R, et $a l$. Endovascular injury induces rapid phenotypic changes in perivascular adipose tissue. Arterioscler Thromb Vasc Biol. 2010; 30: $1576-82$.

50. Iacobellis G, Ribaudo MC, Assael F, Vecci E, Tiberti C, Zappaterreno A, et al. Echocardiographic epicardial adipose tissue is related to anthropometric and clinical parameters of metabolic syndrome: a new indicator of cardiovascular risk. J Clin Endocrinol Metab. 2003; 88: 5163-8.

51. Rittig K, Staib K, Machann J, Bottcher M, Peter A, Schick F, et al. Perivascular fatty tissue at the brachial artery is linked to insulin resistance but not to local endothelial dysfunction. Diabetologia. 2008; 51: 2093-9.

52. Carroll JF, Dwyer TM, Grady AW, Reinhart GA, Montani JP, Cockrell $\mathrm{K}$, et al. Hypertension, cardiac hypertrophy, and neurohumoral activity in a new animal model of obesity. Am J Physiol. 1996; 271 : H373-8.

53. Soltis EE, Cassis LA. Influence of perivascular adipose tissue on rat aortic smooth muscle responsiveness. Clin Exp Hypertens A. 1991; 13: $277-96$.

54. Lohn M, Dubrovska G, Lauterbach B, Luft FC, Gollasch M, Sharma AM. Periadventitial fat releases a vascular relaxing factor. FASEB J. 2002; 16: 1057-63.

55. Dwyer TM, Mizelle HL, Cockrell K, Buhner P. Renal sinus lipomatosis and body composition in hypertensive, obese rabbits. Int J Obes Relat Metab Disord. 1995; 19: 869-74.

56. Danias PG, Tritos NA, Stuber M, Botnar RM, Kissinger KV, Manning WJ. Comparison of aortic elasticity determined by cardiovascular magnetic resonance imaging in obese vs lean adults. Am J Cardiol. 2003; 91: 195-9.
57. Wildman RP, Mackey RH, Bostom A, Thompson T, Sutton-Tyrrell K. Measures of obesity are associated with vascular stiffness in young and older adults. Hypertension. 2003; 42: 468-73.

58. Tounian P, Aggoun Y, Dubern B, Varille V, Guy-Grand B, Sidi D, et al. Presence of increased stiffness of the common carotid artery and endothelial dysfunction in severely obese children: a prospective study. Lancet. 2001; 358: 1400-4.

59. Hall JE, Brands MW, Dixon WN, Smith Jr MJ. Obesity-induced hypertension. Renal function and systemic hemodynamics. Hypertension. 1993; 22: 292-9.

60. Antic V, Kiener-Belforti F, Tempini A, Van Vliet BN, Montani JP. Role of the sympathetic nervous system during the development of obesity-induced hypertension in rabbits. Am J Hypertens. 2000; 13: 556-9.

61. Granger JP, West D, Scott J. Abnormal pressure natriuresis in thedog model of obesity-induced hypertension. Hypertension. 1994; 23: I811.

62. Montani JP, Antic V, Yang Z, Dulloo A. Pathways from obesity to hypertension: from the perspective of a vicious triangle. Int J Obes Relat Metab Disord. 2002; 26 (Suppl 2): S28-38.

63. Hall JE. Mechanisms of abnormal renal sodium handling in obesity hypertension. Am J Hypertens. 1997; 10: 49S-55S.

64. Vanhoutte PM. Obesity and vascular dysfunction: he fat-e of rich and poor. Br J Nutr. 2012, 165: 541-3.

65. Furchgott RF, Zawadzki JV. The obligatory role of endothelial cells in the relaxation of arterial smooth muscle by acetylcholine. Nature. 1980; 288: 373-6.

66. De Mey JG, Vanhoutte PM. Heterogeneous behavior of the canine arterial and venous wall. Importance of the endothelium. Circ Res. 1982; 51: 439-47.

67. Vanhoutte PM. The endothelium-modulator of vascular smooth-muscle tone. N Engl J Med. 1988; 319: 512-3.

68. Furchgott RF, Vanhoutte PM. Endothelium-derived relaxing and contracting factors. FASEB J. 1989; 3: 2007-17.

69. Félétou M, Vanhoutte PM. EDHF: an update. Clin Sci. 2009; 117: 13955.

70. Vanhoutte PM. How we learned to say NO. Arterioscler Thromb Vasc Biol. 2009; 29: 1156-60.

71. Vanhoutte PM. Endothelium-dependent contractions in hypertension: when prostacyclin becomes ugly. Hypertension. 2011; 57: 526-31.

72. Vanhoutte PM, Tang E, Félétou M, Shimokawa H. Endothelial dysfunction and vascular disease. Acta Physiol. 2009; 196: 193222.

73. Garland CJ, Weston AH. The vascular endothelium: still amazing us 30 years on. Br J Pharmacol. 2011; 164: 837-8.

74. Rodriguez-Pascual F, Busnadiego O, Lagares D, Lamas S. Role of endothelin in the cardiovascular system. Pharmacol Res. 2011; 63: 463-72.

75. Rubanyi GM. The discovery of endothelin: the power of bioassay and the role of serendipity in the discovery of endothelium-derived vasoactive substances. Pharmacol Res. 2011; 63: 448-54.

76. Rajsheker S, Manka D, Blomkalns AL, Chatterjee TK, Stoll LL, Weintraub NL. Crosstalk between perivascular adipose tissue and blood vessels. Curr Opin Pharmacol. 2010; 10: 191-6.

77. Vela D, Buja LM, Madjid M, Burke A, Naghavi M, Willerson JT, et al. The role of periadventitial fat in atherosclerosis: an adipose subset with potential diagnostic and therapeutic implications. Arch Pathol Lab Med. 2007; 131: 481-7.

78. Chaldakov GN, Stankulov GN, Aloe L. Sub-epicardial adipose tissue in human coronary athero- sclerosis: another neglected phenomenon. Atherosclerosis. 2001; 154: 237-8.

79. Tellides G. Periadventitial fat: regional source of inflammation in atherosclerosis. Arch Pathol Lab Med. 2007; 131: 346-7.

80. Tore $\mathrm{F}$, Tonches AB, Fiore M, uncel N, Atanassova P, Aloe L, et al. 
From adipose tissue protein secretion to adipopharmacology of disease. Immunol Endocr Metab Agents Med Chem. 2007; 7: 14955 .

81. Gao YL, Lu C, Su LY, Sharma AM, Lee RM. Modulation of vascular function by perivascular adipose tissue: the role of endothelium and hydrogen peroxide. Br J Pharmacol. 2007; 151: 323-31.

82. Chaldakov GN, Tonchev AB, Fiore M, Aloe L, Stankulov IS. Periadventitial adipose tissue (tunica adipose): enemy or friend around. Arch Pathol Lab Med. 2007, 131: 1766.

83. Fortuno A, Rodriguez A, Gomez-Ambrosi J, Fruhbeck G, Diez J. Adipose tissue as an endocrine organ: role of leptin and adiponectin in the pathogenesis of cardiovascular diseases. J Physiol Biochem. 2003; 59: 51-60.

84. Thalmann S, Meier CA. Local adipose tissue depots as cardiovascular risk factors. Cardiovasc Res. 2007; 75: 690-701.

85. Yamawaki H, Tsubaki N, Mukohda M, Okada M, Hara Y. Omentin, a novel adipokine, induces vasodilation in rat isolated blood vessels. Biochem Biophys Res Commun. 2010; 393: 668-72.

86. Fesus G, Dubrovska G, Gorzelniak K, Kluge R, Huang Y, Luft FC, et al. Adiponectin is a novel humoral vasodilator. Cardiovasc Res. 2007; 75: 719-27.

87. Gao YJ, Takemori K, Su LY, An WS, Lu C, Sharma AM, et al. Perivascular adipose tissue promotes vasoconstriction: The role of superoxide anion. Cardiovasc Res. 2006; 71: 363-73.

88. Gollasch M, Dubrovska G. Paracrine role for periadventitial adipose tissue in the regulation of arterial tone. Trends Pharmacol Sci. 2004; 25: 647-53.

89. Fortuno A, Rodriguez A, Gomez-Ambrosi J, Muniz P, Salvador J, Diez $\mathrm{J}$, et al. Leptin inhibits angiotensin II-induced intracellular calcium increase and vasoconstriction in the rat aorta. Endocrinology. 2002; 143: 3555-60.

90. Engeli S. Is there a pathophysiological role for perivascular adipocytes? Am J Physiol Heart Circ Physiol. 2005; 289: H1794-5.

91. Schleifenbaum J, Kohn C, Voblova N, Dubrovska G, Zavarirskaya $\mathrm{O}$, Gloe $\mathrm{T}$ et al. Systemic peripheral artery relaxation by KCNQ channel openers and hydrogen sulfide. J Hypertens. 2010; 28: 187582.

92. Yang G, Wu L, Jiang B, Yang W, Qi J, Cao K et al. $\mathrm{H}_{2} \mathrm{~S}$ as a physiologic vasorelaxant: hypertension in mice with deletion of cystathionine gamma-lyase. Science. 2008; 322: 587-90.

93. Feng X, Chen Y, Zhao J, Tang C, Jiang Z, Geng B. Hydrogen sulfide from adipose tissue is a novel insulin resistance regulator. Biochem Biophys Res Commun. 2009; 380: 153-9.

94. Fang L, Zhao J, Chen Y, Ma T, Xu G, Tang C, et al. Hydrogen sulfide derived from periadventitial adipose tissue is a vasodilator. $\mathrm{J}$ Hypertens. 2009; 27: 1034-49.

95. Gollasch M. Vasodilator signals from perivascular adipose tissue. Br J Pharmacol. 2012; 165: 633-42.

96. Ichiki T. Perivascular Adipose Tissue, a janus-faced regulator of vascular function. Circ J. 2010; 74: 1300-1.

97. Skilton MR, Serusclat A, Sethu AH, Brun S, Bernard S, Balkau B, et al. Noninvasive measurement of carotid extra-media thickness: Associations with cardiovascular risk factors and intima-media thickness. JACC Cardiovasc Imaging. 2009; 2: 176-82.

98. Aghamohammadzadeh R, Withers S, Lynch F, Greenstein A, Malik R, Heagerty A. Perivascular adipose tissue from human systemic and coronary vessels: the emergence of a new pharmacotherapeutic target. Br J Pharmacol. 2012, 165: 670-82.

99. Lusis AJ. Atherosclerosis. Nature. 2000; 407: 233-41.

100. Ross R. The pathogenesis of atherosclerosis: a prospective for the 1990s. Nature. 1993; 362: 801-9.

101. Ross R. Atherosclerosis - an inflammatory disease. N Engl J Med. 1999; 340: 115-26

102. Tedgui A, Mallat Z. Cytokines in atherosclerosis: pathogenic and regulatory pathways. Physiol Rev. 2006; 86: 515-81.

103. Doran AC, Meller N, McNamara CA. Role of smooth muscle cells in the initiation and early progression of atherosclerosis. Arterioscler Thromb Vasc Biol. 2008; 28: 812-9.

104. Maiellaro K, Taylor WR. The role of the adventitia in vascular inflammation. Cardiovasc Res. 2007; 75: 640-8.

105. Karastergiou K, Mohamed-Ali V. The autocrine and paracrine roles of adipokines. Mol Cell Endocrinol. 2010; 318: 69-78.

106. Henrichot E, Juge-Aubry CE, Pernin A, Pache JC, Velebit V, Dayer $\mathrm{JM}$, et al. Production of chemokines by perivascular adipose tissue: a role in the pathogenesis of atherosclerosis? Arterioscler Thromb Vasc Biol. 2005; 25: 2594-9.

107. Libby P, Ridker PM, Maseri A. Inflammation and atherosclerosis. Circulation. 2002; 105:1135-43.

108. Moreno PR, Purushothaman KR, Fuster V, O'Connor WN. Intimomedial interface damage and adventitial inflammation is increased beneath disrupted atherosclerosis in the aorta: implications for plaque vulnerability. Circulation. 2002; 105: 2504-11.

109. Pietrobelli A, Boner AL, Tato L. Adipose tissue and metabolic effects: new insight into measurements. Int J Obes Relat Metab Disord. 2005; 29: S97-100.

110. Maurovich-Horvat P, Massaro J, Fox CS, Moselewski F, O’Donnell $\mathrm{CJ}$, Hoffmann U. Comparison of anthropometric, area- and volumebased assessment of abdominal subcutaneous and visceral adipose tissue volumes using multidetector computed tomography. Int $\mathrm{J}$ Obes. 2007; 31: 500-6.

111. Fluchter S, Haghi D, Dinter D, Heberlein W, Kühl HP, Neff W et al. Volumetric assessment of epicardial adipose tissue with cardiovascular magnetic resonance imaging. Obesity (Silver Spring). 2007; 15:870-8.

112. Schlett CL, Massaro JM, Lehman SJ, Bamberg F, O'Donnell CJ, Fox CS, et al. Novel measurements of periaortic adipose tissue in comparison to anthropometric measures of obesity, and abdominal adipose tissue. Int J Obes. 2009; 33:226-32.

113. Iacobellis G, Assael F, Ribaudo MC, Zappaterreno A, Alessi G, Di Mario U, et al. Epicardial fat from echocardiography: a new method for visceral adipose tissue prediction. Obesity. 2003; 11: 304-10.

114. Miao CY, Li ZY. The role of perivascular adipose tissue in vascular smooth muscle cell growth. Br J Phamacol. 2012; 165: 643-58.

115. Liu J, Fox CS, Hickson DM, Sarpong D, Ekunwe L, May WD, et al. Pericardial adipose tissue, atherosclerosis, and cardiovascular disease risk factors. Diab Care. 2010; 33: 1635-9.

116. Boettcher M, Machann J, Stefan N, Thamer C, Haring HU, Claussen $\mathrm{CD}$, et al. Intermuscular adipose tissue (IMAT): association with other adipose tissue compartments and insulin sensitivity. J Magn Reson Imaging. 2009; 29: 1340-5.

117. Barrett EJ, Eggleston EM, Inyard AC, Wang H, Li G, Chai W, et al. The vascular actions of insulin control its delivery to muscle and regulate the rate-limiting step in skeletal muscle insulin action. Diabetologia. 2009; 52: 752-64.

118. Eringa EC, Bakker W, Smulders YM, Serne EH, Yudkin JS, Stehouwer CD. Regulation of vascular function and insulin sensitivity by adipose tissue: focus on perivascular adipose tissue. Microcirculation. 2007; 14: 389-402. 